\title{
NIELS FOCK
}

\section{TIL FESTBANKET I JUNCAL}

\section{Madens sociale og kulturelle betydning hos nogle indianere i Andes}

Fordi mad er en nødvendighed, har vi vænnet os til at betragte den som en selvfølgelighed. Det er et spørgsmål om daglig kost eller festmad, om hurtig mad eller ordentlig bordskik, men maden får vi, og vore bekymringer går snarere på hvorfra den kommer, hvilke industrielle processer den har været underkastet, eller hvilke skjulte risici den måtte indebære. Jeg vil forsøge at skildre madens plads i et meget anderledes samfund end vort, nemlig i en indiansk landsby, Juncal i Ecuadors bjerge i Cañarprovinsen. ${ }^{1}$

\section{Stedet}

Det mest overraskende er måske at det er så synligt og rumligt alt sammen. Landskabet, en frodig, kuperet skråning omkring de $3000 \mathrm{~m}$ over havet og kun et par grader syd for ækvator, der af vandingskanaler og stier inddeles i en småternet mosaik af marklodder, afslører så at sige menuen i de cirka 200 huse der er tale om. Den friskgrønne majs fortæller om en af delikatesserne, kogte friske majskolber, blomstrende kartoffelmarker om nye kartofler med chili, og den gyldne byg giver løfte om simpel overlevelse på talløse supper brygget på ristet og malet byg.

Ser man ud over dette panorama, vil man snart få øje på enkelte sortklædte juncalbønder med de typiske hvide filthatte arbejdende i marken, og man vil ved middagstid se klynger af dem, familien og et par venner og slægtninge, der udgør et arbejdsfællesskab, en minga. De betjenes af husets kvinder i deres røde skørter, som bringer forfriskninger i form af majs $\emptyset \mathrm{l} \mathrm{og} \mathrm{kurve} \mathrm{med} \mathrm{mad} \mathrm{som} \mathrm{tak} \mathrm{og} \mathrm{betaling} \mathrm{for} \mathrm{de} \mathrm{fremmedes} \mathrm{indsats.} \mathrm{Ma-}$ dens synlighed hænger direkte sammen med at man i Juncal stadig lever med en subsistens $\varnothing$ konomi hvor mad og fødevarer er vigtigste betalingsmiddel. Penge findes - om end kun sparsomt - men det betragtes hverken socialt eller økonomisk som tilfredsstillende at betale daglejere i penge, blandt andet pga. den permanente inflation.

Spredt ud mellem markerne ligger husene, små lerklinede huse med strå- eller bølgeblikstage, eller rettere gårdene, for de består af en indhegnet gårdsplads til dyr og redskaber, et beboelseshus med åben korridor og i vinkel herpå et mindre køkkenhus uden skorsten, hvorfra røg permanent siver ud ved gavlene. Lige op til gårdspladsen findes altid en urtehave der foruden lidt $l \varnothing g$ og kål rummer krydderurter og medicinske urter 
samt eventuelt et frugttræ. Urtehaven er essentiel ved tilberedning af maden fordi denne altid skal tempereres. Cañar-indianerne er ekstremt dualistisk orienterede og deler alle fødemidler op i enten varme eller kolde, ja det gælder faktisk alting i denne verden. For at en mand kan bevare sin tempererede og sunde tilstand, må hans kone i køkkenet kombinere de rigtige ting og eventuelt justere ved hjælp af krydderier og medicinske urter fra køkkenhaven.

Det varme og det kolde har ikke noget med temperatur at gøre, men er et rent kulturelt klassifikationssystem, som juncalenerne har spundet sig selv ind i. De er selv tempererede og skal forblive sådan, og deres levested er i øvrigt også opfattet som tempereret i forhold til geografien, idet de lever mellem oppe og nede (jawa og ucu), hvilket her vil sige mellem paramo'ens bjergtinder i nordøst og Cañarflodens slugter i sydvest. Endelig betragter de deres territorium som liggende mellem det tørre Cañarbækken i sydøst og det våde nordvestområde hvor fx el Niño med års mellemrum hærger. I folkemunde skelnes der mellem ,,avner og snot“, dvs. mellem tørre stubmarker og dryppende bjergskove.

Disse rumlige distinktioner optræder som en erstatning for de sæsonmæssige vi normalt er underlagt. Sagen er at der i Juncal, næsten lige under ækvator, bogstaveligt ingen temperaturforskel er året igennem, cirka 1 grad omkring de 11 graders gennemsnit. Klimaet, og dermed afgrøderne og deres vækstperiode, er derfor bestemt ikke af årstid, men af højden over havet, og mens man på de højeste jorder må afse næsten et år på en afgrøde af kartofler eller byg, så kan man i de lunere strøg tage op til to en halv afgrøde årligt. Da hver bonde har sin jord spredt i smålodder både oppe og nede, medfører disse betingelser at han altid kan være beskæftiget med både at så, plante, luge og høste, og at han hele året rundt kan regne med forskellige afgrøder. Dette meget arbejdsintensive system bruges kun af indianerne; de hvide og mestizerne søger at samle deres jord og tager kun én årlig afgrøde med høst i august, som de på europæisk vis kalder for sommer, om end det er årets koldeste måned.

Juncals kunstvandingsagerbrug med dets forskudte vækst- og høstperioder er den naturlige baggrund for en permanent subsistensøkonomi, og for billedet af en kalejdoskopisk skiftende landskabelig mosaik hvor der altid er behov for markarbejde. Maden der spises her er synlig på marken og er rumligt fordelt i kraft af de ekstraordinære naturbetingelser og de kulturelle koder juncalenerne har nedlagt $\mathrm{i}$ landskabet. Man tænker også i rumlige kategorier. Hvis en mand kommer sulten hjem og spørger konen hvor længe det varer med maden, kan hun svare „køkkenet er i Charcayhuaycu“! Det vil sige den tid, det tager at gå hjem fra et kendt sted, i dette tilfælde cirka et kvarter. Eller hun peger blot med munden imod en eller anden lokalitet. Således transformeres ventetid til afstand.

\section{Myten}

Den familie der ejer 1-2 hektar land og har energien kan brødføde sig selv, men mange har for lidt jord. Nogle er enlige, og uheldet kan være ude. Nattefrosten kan svide planterne, el Niños udløbere kan med voldsom regn erodere de skrånende marker trods terrasseringen, og sulten bliver en reel risiko. I Juncal forestiller man sig meget konkret at livsbetingelserne fastlægges, og det kommende års succes tildeles oppefra. Nok er disse folk katolikker i det ydre, men mere grundlæggende ser de deres eksistens som afhængig af to mytiske væsner der bor i nogle af de højeste bjerge i området. Den ene er Urcuyaya 
- den gamle i bjerget - der, hvad frugtbarhed angår, råder over alt levende ned ad bjergets skråninger, og den anden er Taita Carnaval eller Fader Karneval. Sidstnævnte synes at implementere Urcuyayas kraft ved årligt at fordele held og uheld blandt Juncals hushold.

Om Taita Carnaval fortælles at han er en gammel mand der hvert år i februar kommer vandrende ned over Juncals skråninger fra de høje bjerge i nordøst. Han når frem til husene karnevalsmandag og forsvinder nedover dagen efter iført sit særlige udstyr med gedehårsbukser og en kæmpemæssig okseshudshat, der her på egnen bruges som beskyttelse mod bolaslag og slyngesten. Han medbringer en fløjte (pingullu, skåret af kondorens vingeben) og en lille tromme af guld. Kondoren hentyder til de højder han kommer fra, og guldet at han kommer inde fra bjerget, som netop åbner sig i februar måned. Endelig har han en cabuyataske med mad i.

Taita Carnaval kommer for at besøge husholdene og efterlade held hos dem, men han er ikke alene. I følge med ham går en person som kaldes Yarcay, og som er „Sulten“. Han har ingen særlige kendetegn ud over at han intet har, heller ikke ordentlig mad i sin taske, og derfor havde Taita Carnaval allerede på den lange vandring måttet byde Yarcay af sin lækre mad med stegt cui (marsvin) osv. Yarcay følte sig flov over at byde på sin mad, der bestod af tynde kartofler med skræl, agerkål og lidt ristet majs. Da de nåede frem, havde også Taita Carnaval derfor opbrugt al sin mad og måtte det sidste stykke vej nøjes med tilfældige vilde planter og frugter.

Taita Carnaval kommer for at besøge juncalindianernes huse, men han går kun ind i dem, der er gjort pænt i stand og ikke er rodede eller uhumske, og kun hvis der er dækket et ordentligt bord til ham. I hovedhusets korridor er der dækket op til festmåltid, dvs. hele bordet er fyldt op med mote (muti, udvasket, kogt majs), papa (kogte skrællede kartofler), med uchu (chilipeber), velsaltet cui (marsvin) og i hjørnerne brød formet som duer, der sidder i achupalla-(cabuya-)planter, og hvori der er stukket blomster. Endelig er der godt med chicha (asua, majsøl) og trago (sukkerrørsbrændevin fra kysten). Der er tale om juncalenernes typiske festmåltid eller banket: et overflødighedshorn af de bedste spiser præsenteret alt på en gang og i høje bunker.

Det ejendommelige ved disse karnevalsbanketter er at værten ikke selv er til stede, så føler Taita Carnaval sig nemlig mere fri til at gå ind. Næste dag, når værtsfolkene kommer tilbage, kan det godt være at maden står der endnu, men så vil man opdage at marsvinet har mistet sin lækre salte smag, og tragoen har tabt i alkoholprocent. Så har Taita Carnaval alligevel været der, og den mad og drikke han har modtaget som offer vil sikre husholdet mod allehånde uheld og sikre en god høst. Normalt vil man dog finde bordet ribbet, simpelthen fordi folkene i karnevalsdagene „bytter gårde“, de forlader deres eget hus med det veldækkede bord for at besøge andre huse og venner i stedet og overlader som regel værtskabet til en ældre kvindelig slægtning. Således sker der en anonymisering - ikke som vi kender det fra fastelavn ved hjælp af maskeklædte unge der kommer for at få - men ved at sociale personer fjerner sig fra hjemmet for at give. Det er konteksten der er udskiftet, og heldet rammer uden persons anseelse.

Når så Taita Carnaval sætter sig til bords, er det dog ikke kun for selv at spise. Nej, han fylder sin taske med mad, og på sin videre vandring deler han den ud til alle de børn han møder. Ilde er det for den der ikke ejer fødevarer til karnevalsbordet, og som Taita og heldet derfor ikke gæster. Han risikerer i stedet at få besøg af Sulten.

Yarcay sætter sig i sine laser ved ildstedet i køkkenet, og der bliver han siddende lige til næste høst, og der bliver intet tilbage til familien. Karnevalstiden omfattes af junca- 
lenerne med den største følelsesmæssige interesse; det er her ved åbningen af et nyt år at held og frugtbarhed for hele året skal sikres, om man vil få nok at spise, eller der vil herske smalhals.

Der findes mange andre skikke i forbindelse med Taita Carnaval, der handler om individuelle møder med ham og bolakampe for at afvriste ham heldet, ligesom samfundets to halvdele også tidligere udkæmpede slyngekampe med samme formål (Krener \& Fock 1979), men her er der især grund til at hæfte sig ved karnevalsbanketten - juncia kaldes den - som jo tydeligvis ikke er privat, men anonymiseret til en offentlig begivenhed, et ritual. Ofte finder man at maden indgår med symbolsk vægt i offerritualer, men her er selve banketten den performance der demonstrativt viser hele samfundets behov. Det kollektive understreges også af den redistributive handling når Taita Carnaval genfordeler goderne.

Festbanketter benyttes ud over ved fastelavn også ved enkelte større fester i løbet af året, især nogle af de kalendariske helgenfester hvor en tilstrækkeligt velbeslået sponsor kan byde på banket. Der er grund til også her at bemærke det rumliges dominans i forhold til det tidslige. $\mathrm{Al}$ maden præsenteres på en gang, og honoratiores placeres på småstole ved bordet, mens andre mænd sidder tæt ved, og kvinder og børn i periferien. Her er ikke brug for service, kvinderne rækker blot deres bowlerformede filthat ind til deres ægtemand, der så forsyner dem med mote, kartofler med chili og eventuelt et stykke kød fra bordet. Der er således tale om at alle spiser alt samtidigt, men i et radiært mønster.

Det står i eklatant kontrast til den måde mestizerne på pladsen serverer mad på. Her sidder kun mændene til bords, mens kvinderne løber til og fra køkkenet. Man har nærmest demonstrativt accentueret den tidslige succession ved ikke blot at skille retterne, men også ingredienserne. Først får man fx en klar suppe med mote, så et par velvoksne kartofler, derefter blomkål og så gulerødder for endelig at slutte af med ris og hønsekød, clouet. Først derefter får man noget at drikke, først chicha, siden trago. Kvinderne spiser bagefter i køkkenet. Der er også en åbenbar strukturel kontrast mellem mestizernes afsluttende ris med hønsekød, og indianernes kartofler med marsvin der troner på bankettens top.

\section{Produkterne}

Ud over spørgsmålet om tid versus rum er der meget væsentlige forskelle mellem vor og juncalenernes opfattelse og brug af mad. Ganske vist har de indført en række af den gamle verdens kulturplanter og husdyr: byg og hvede, ærter og alternative bønnesorter, løg og kål, svin, får og geder, høns samt lidt kvæg for blot at nævne det vigtigste. Vi har ikke været helt så dygtige til at anerkende deres langt talrigere kulturplanter; det er forblevet ved især kartofler og majs. Men juncalenerne har altså beriget deres assortiment, og fra den nærliggende tropezone både mod kysten og Amazonas indfører de mere sporadisk produkter som ris, bananer og appelsiner. Alligevel er deres daglige kost meget traditionel og enkel, og dyrkningen af hvede har fx ikke ført til at man kan tale om det daglige brød. Tværtimod er brød noget man højst bager et par gange om året til brug ved festbanketter, eller man køber lidt på markedet for afvekslings skyld.

Kosten er decideret præget af søbemad, supper eller vællinger (api) og det, man kalder café, der er en morgendrik, som kun sjældent har noget med kaffe at gøre, men grund- 
læggende består af ristet og malet byg opløst i kogt vand, enten varmt eller koldt. Man skelner mellem våde og tørre retter, sopas og secos, men det er sigende for forholdet dem imellem at ingen juncalenere har gafler; de har kun brug for en ske og en sjælden gang en kniv. Det hænger sammen med at grønsagerne altid koges og som regel serveres i suppen. Også kød koges normalt for at give suppen kraft, og i øvrigt må juncalenerne i det daglige nærmest betragtes som vegetarer fordi der ikke er råd til kød. Deres egne dyr er normalt beregnet til salg på markedet. Hjemmeslagtning finder dog sted, enten hvis man skal være sponsor for en større helgenfest, eller hvis der er sikkerhed for et rimeligt lokalt salg. Den pengesparsomme $\emptyset$ konomi, og en typisk mistillid til at ens nære bekendte vil betale prisen, vanskeligg ør slagtninger og et lokalt forbrug af $k \varnothing \mathrm{d}$. Den store undtagelse i hele denne situation er marsvinet som i stort tal gemmer sig under bænkene i de lune køkkener. På grund af dets størrelse kan det indtage en plads svarende til vores fordums søndagskylling. Det skiller sig også ud ved næsten altid at blive spidstegt og indgå i de tørre retter.

Selv for et så simpelt køkken som cañarindianernes er det ret kompliceret at redegøre for rationalet i dets sammensætning. Fem forskellige perspektiver påvirker resultatet, nemlig det ernæringsmæssige - at blive mæt; det gastronomiske - at det smager godt; det diætetiske eller det medicinske - at man opretholder sundheden; det sociale - at man udveksler mad for arbejde og byder andre det bedste; og endelig det spektakulære hvor mad bruges som middel til at opretholde status og prestige i samfundet. Disse fem perspektiver, der går fra det mest konkrete til det abstrakte, væver sig ustandseligt ind i hinanden.

\section{Ernæringen}

At holde sulten fra døren er jo det første. Det hævdes - og vi har mødt eksempler derpå - at en enlig, fattig juncalener kan klare sig over længere tid med et pund machca, dvs. ristet malet byg, dagligt, som man hjemme kan koge suppe (café) på, men som man også medbringer som pulver i en taske når man arbejder ude og da kan spise tørt sammen med en slurk vand. Fire gange machca om dagen er ikke dyrt, og det er heller ikke sjovt, men man kan overleve på det. Machca indgår altid i mindst to af dagens måltider, nemlig den årle morgenmad chinzhina eller café ved 5-6 tiden og i enten middags- eller aftensmaden. Der er dog den forskel at mens morgenmaden normalt er sødet, er resten af dagens måltider salte.

Når vi taler om den daglige kost som simpel energikilde, så er den hos juncalenerne karakteriseret ved at være våd, vegetarisk og stivelsesholdig. Hovednæringsmidlerne ved siden af byg er kartofler, majs og bønner. Rodfrugterne der kan gro højest oppe, omfatter foruden mere end 20 sorter kartofler også beskedne mængder af oca, millucu og mashua. Kornsorterne er domineret af majs (sara) og byg, men også hvede, mens den indianske quinua er sparsom. Endelig spiller de proteinrige bælgplanter en stor rolle, dels de indfødte bønner (purutu), men også de indførte habas, ærter og linser, der som regel dyrkes sammen med majsen. Disse planter sikrer mindst $90 \%$ af føden, og det eneste væsentlige tilskud udefra er den ris der købes på markedet. Med hensyn til prestigemad kan man konstatere at det kun er købte produkter - ris, pasta, nudler og brød fx - der tillægges særlig prestige, mens indførte, men lokalt dyrkede afgrøder som fx byg og den brede haba-bønne stigmatiseres som indiansk af lokale mestizer. 
Når jeg karakteriserer dagligkosten som våd, er det både fordi den normalt er kogt, og fordi den serveres som suppe eller vælling. Hvis man spiser hjemme i køkkenet midt på dagen (micuna), vil dagens ret - alt efter ens afgrøders modning - bestå af en suppe på kartofler, byg eller majs. Det kogte vand jævnes med mel, krydres med salt og chilipeber, eventuelt lidt løg fra køkkenhaven, og heri koges kartoflerne, som dog skal være faste. Ofte spises der mote til, de udvaskede og i timer kogte hårde majskerner, der er som bløde popcorn. Variationerne er at man, hvis man har husdyr, kan legere suppen med et æg eller mælk, eller at man kan give den kraft fra et stykke flæsk eller charqui, dvs. soltørrede oksekødsstrimler der kan opbevares 3-4 måneder. Man kan også spise kartofler og/eller mote ved siden af, og så som tilbehør få lidt quesillo, den friske feta-agtige ost med chili og salt. Ernæringsmæssigt er det imidlertid af stor betydning at dette suppemønster brydes på forskellig måde i forbindelse med både arbejde og fest. Her træder dels de tørre spiser (secos) ind af praktiske årsager og kødet af sociale og prestigemæssige grunde.

Arbejde på en fjerntliggende mark kan betyde at man ikke kan nå hjem til middagen, og i så fald tager man tørkost med i en kurv eller taske. Det vil igen være kogte kartofler, mote eller machca, lidt salt og chili. Sådan en madpakke kan en mand også medbringe hvis han er kaldt til ayudana hos en af sine arbejdsudvekslingsvenner. Ayudana betyder ,at hjælpe" på reciprocitetsbasis, og i denne situation lægger man et dagværk, som siden betales ved at værten gør gengæld når der kaldes. Normalt modtager man da kun forfriskninger i form af chicha og trago. Men nogle gange stiller værten an med både mad og drikke, og så bliver konerne også indbudt, og det kaldes minga.

\section{Social mad}

Minga er fællesarbejde og betragtes af juncalenerne som en af de vigtigste sociale og $\emptyset$ konomiske institutioner i samfundet, bl.a. fordi det garanterer både hyggeligt, socialt samvær og bedre mad end til daglig. En minga kan være lille eller stor, den kan indskrænke sig til indbydelsen af en til to gode venner eller naboer, for at få overstået plantning, lugning eller høst af en mark på en dag. Det kan også foregå i forbindelse med husbygning eller tækning af et hus hvor man har brug for et par ekstra hænder og eventuelt et muldyr for at hente ichu-græs fra paramo'en. I så fald er mændene nødt til at spise langt fra hjemmet og får fx kogte kartofler med chili og spidstegt marsvin med på turen foruden den obligatoriske chicha. En sådan lang arbejdsdag kan rundes af med at værtens kone har lavet klar suppe på et stykke oksekød der serveres med varme kartofler til. Med rigelig brændevin tager man sig måske en svingom til musikken fra radioen eller en fløjte. Arbejdet er blevet til en fest.

At deltage i minga, dvs. at hjælpe hinanden i arbejdet og blive belønnet med god mad og drikke og oven i købet have en god tid sammen, er utvivlsomt den vigtigste sociale adfærd, man kan fremvise her. Jo flere minga'er, man indbyder til, jo bedre status har man. Nogle af de mere velstående bønder prøver ganske vist at komme uden om et så krævende gensidigt samarbejde ved at udbetale daglønninger i stedet for mad, men det vinder man ikke prestige på. Det er i øvrigt også bemærkelsesværdigt at man ved de små minga'er ikke indkalder slægtninge så meget som venner. Ideen synes at være at slægtninge under alle omstændigheder vil modtage mad som en gave fra husmoderen og derfor ikke er motiverede for en arbejdsindsats. 
Minga'er gør altså arbejdslivet socialt værdifuldt, samtidig med at de sikrer at man nu og da får et tilskud af animalsk protein i form af stegt marsvin, eller kogt fåre- eller oksekød hvis det er en større minga.

I forbindelse med større offentlige arbejder, som kanalrensning eller vejbygning, afholdes der hvad man kalder tør-minga (chaquiscamingay), hvilket netop hentyder til madens karakter. Her er der ingen vært, men en $\emptyset v$ righedsperson sørger for at indkalde en arbejdsfør person fra hvert hushold til dagens arbejde. Er han forhindret i at komme, har hans kone pligt til at stille med en kurv mad midt på dagen. De der prøver at snyde sig fra det afkræves en dagsløn i penge der delvis anvendes til brændevin. Tør bliver sådan en ming $a$ altså langt fra i vor forstand af ordet, men madtraktementet vil bestå af en række kurve med henholdsvis kogte majskolber, mote, kartofler, linser, en mindre skål med kød og en med quesillo og chili.

\section{Smagen}

Den mad man således nyder ude som hjemme, er altid underkastet to modifikationer: en gastronomisk, som har med smagen at gøre, og en tempererende, som har med det dualistiske system af kolde og varme ting at gøre.

Hvis der er en ting juncalenerne ikke kan lide, så er det det smagløse, fade (gamu). Der går frasagn om noget spidstegt kød som man havde glemt at salte, og som ingen kunne spise, og når man koger kartoflerne med skræl, vil man oftest skrælle et bælte af for at saltsmagen kan trænge ind, ellers smager det $\tilde{n} u g \tilde{n} u$, for glat eller smagløst. Jeg tror, man må sige at de positive gastronomiske smage begrænser sig til tre: sødt, salt og stærkt. Klassifikatorisk er det lidt kompliceret, idet quechua-ordet mishqui primært betyder velsmagende, men det deles så i mishqui mishqui, der betyder sødt, og cachi mishqui, der står for velsaltet. Hvis maden indeholder for meget salt, kaldes den salag. Det meste mad - fx majs, kartofler og kød - regnes fra naturens hånd som smagløst, og man kan derfor betragte krydderierne som information der tilføres føden, der selv er ren energi. Den tredje smag er jayag der også deles i henholdsvis uchu jayag (chili, pikant og stærk) og sacha jayag (vild bitter) hvor sidstnævnte ikke bruges i madlavning, men kun som medicin. Om agrio eller pucushca, der betyder surt, er en gastronomisk smag er tvivlsomt fordi den er forbundet med gæring og forrådnelse, og citron fx ikke bruges i madlavning.

Med hensyn til smagspræferencer synes juncalenerne at dele sig op i dem der foretrækker chili-pikant, og dem der er til salt. Jayag/mishqui dualismen synes at afspejle en kønsdistinktion, idet det stærke jayag har en vis macho- og mandstilknytning. Smagskvaliteterne i maden skabes først og fremmest ved madlavningen, og ved tilsætning af ingredienser der hidrører fra køkkenhaven. De store undtagelser herfra er naturligvis salt og sukker der købes på markedet. For begge produkter er det vigtigt at skelne mellem den grove uraffinerede og den fine raffinerede vare, henholdsvis stensalt $\mathrm{i}$ krystaller og brun panela, melassesukkermasse, over for hvidt bordsalt og sukker. Ikke blot har de to slags salt og sukker forskellig smag og brug, de tempererer også maden forskelligt, som det vil fremgå nedenfor.

Men de egentlige krydderier kommer fra de små, intensivt dyrkede køkkenhaver, som ofte rummer en eller flere chilipeberbuske ( $u$ chu) og spansk peber (rucutu), og hvor der i øvrigt dyrkes lidt koriander, kommen, melisse, løvstikke og rosmarin til at sætte 
smag på især suppen. Men når talen er om disse sekundære krydderier, så er der en flydende grænse til de medicinske urter. Det er værd at bemærke at også i europæisk middelalder blev disse krydderier betragtet som lægeurter, og køkkenhaverne i Juncal rummer mange indslæbte, vilde planter som kamille, malve, hjulkrone, viol, fuchsia og stedmoderblomst, for blot at nævne nogle få der mere tempererer maden end tilsmager den.

Køkkenhaverne indeholder som regel også lidt grøntsager hvor løg er vigtigt, men også gulerødder, kål eller salat kan optræde. Endelig er der lidt frugttræer eller -planter som fx capuli og chamburu, passionsblomst og jordbær - alle oprindelige indianske planter - lidt prydplanter, nemlig roser, geranier og tekniske planter, hvor en bananart skal fremhæves, fordi dens blade bruges til at pakke krydret majsmasse ind i til de lækre tamales eller humitas (af frisk majs). Humitas (chiwilla) udgør i øvrigt en særlig slags mad, der kaldes wanlla og betyder mad beregnet til at tage med sig hjem. Chili laves også til en stærk sovs på en speciel morter i køkkenet (uchu rumi) hvor man støder stensalt, løg og achote (farvestof) sammen med chili. Ofte serveres denne sovs sammen med lidt ,fetaost" til fx kogte kartofler: en sikker kulinarisk favorit.

\section{„Varm“ og „kold“ mad}

Som nævnt ovenfor er der en glidende overgang mellem krydderurter og lægeurter, og det er da også sådan at krydderier i Juncal ud over at indgå i en smagsklassifikation indgår i et langt mere omfattende dualt system, der deler ting op i henholdsvis de varme (cunug) og de kolde (chiri). Det gælder ikke blot planterne, men alle fødemidler, ja alting i verden betragtes som elementer, der har enten varme eller kolde egenskaber. Disse kategorier har ikke noget med temperatur at gøre, men snarere med temperament, idet det er deres indvirkning på menneskets velbefindende der er på spil. Mennesket er det eneste væsen der fra naturens side er tempereret og som skal holde denne balance, på samme måde som Juncal ligger i den tempererede zone mellem oppe og nede og mellem det tørre og våde.

Mennesket består af et varmt indre (shungu) og et koldt ydre (kanzha), på samme måde som ægget hvis blomme er varm og hvide er kold. Spisning er derfor ikke kun tilfredsstillelse af energibehov og nydelse, men en livslang profylakse hvor kostens elementer skal afstemmes og finjusteres ved hjælp af krydderier og andre planter, der ikke synes at have anden funktion end den medicinske, tempererende. Et sådant humoralt system var også i funktion i europæisk middelalder, og det er et spørgsmål om ikke mange krydderier netop har deres oprindelse i et medicinsk system. Fx regnes i Juncal alle pebrede og bitre smagsstoffer som varme, og der er en almindelig opfattelse af at de varme fødemidler er de mest styrkende og vitaminrige - hvilket her nærmest må betyde sunde. Rent faktisk er chilipeber kendt for at være ekstraordinært rig på C-vitamin.

Som tidligere omtalt koger man altid kartofler med salt i vandet. De smager bedst sådan, men det er langtfra alt hvad der er til det. Kartofler er varme, og de vil fortrinsvis blive spist sammen med chili der også er varmt, og derfor må de koges med salt der er koldt. Vi kunne også kynisk sige at derfor må salt være koldt. Det er nemlig sådan at komparative undersøgelser i Andesområdet afslører at der er tale om en ad hoc-klassifikation. Det er ikke vigtigt at fx kartofler er varme eller salt koldt, men derimod at når kartofler er varme, så er salt koldt. Det er altså ikke elementernes temperatur, der fikseres 
på, men derimod deres indbyrdes relationer i forhold til mennesket. Når man som her har en rimelig fordeling af de forskellige typer af fødemidler i henholdsvis varme og kolde kategorier, kan systemet fungere.

I Juncal er således fx kartofler, quinua, og hvede, rødløg, bønner, det store zapallogræskar, chili, hvidløg, løvstikke, appelsin, banan, brombær og capuli varme, mens millиси, majs, byg, almindelige løg, gulerødder, salat, zambo-græskar, salt, sukker, citron, platano, jordbær og chamburu regnes for kolde. Man skal bemærke den alsidighed og parallelisme der findes de to kategorier imellem. Der ville ingenting ske ved at bytte om på de to lister når endemålet blot er at kunne indtage en afbalanceret kost. Tilsvarende er de animalske produkter delt med marsvin, okse og ged som varme og kylling, får og svin som kolde.

Men dette rigide system indeholder også en vis dynamik, som blandt andet har med forarbejdningsgraden at gøre. Jeg nævnte at kartoflerne skulle koges med salt, men det er vigtigt at det er stensalt og ikke bordsalt, for ved denne raffinering ændrer salt sig fra koldt til varmt. Omvendt går det med sukker hvor det uraffinerede og kalkholdige panela er varmt, mens det fine sukker er koldt, hvilket kan siges at være heldigt, eftersom kaffe er varmt. Samstemmende hermed er gæret majs $\varnothing l$, chicha de jora, koldt, mens det $\varnothing \mathrm{l}$ der laves af den hårde morocho-majs iblandet panela er varm; $\varnothing 1$ kan man således altid nyde uanset temperatur. I $\varnothing v$ vrigt er brændevin koldt og tobak varmt, og de går derfor godt sammen.

Ser vi lidt på den tilberedte mad og retterne, er det således at både majs og mote med skal er koldt, mens den afskallede er varm, og machca - den ristede byg der males er kold hvis den males ved maskinkraft, men varm - og bedre - hvis den males i håndkværn. Forarbejdningsgraden er altså en vigtig faktor ved kategoriseringen. Det gælder måske også for retterne. Det er sådan at vand er koldt, og ild er varmt, meget naturligt vil man sige, men det er også sådan at kogende vand er meget koldt! Det er måske baggrunden for at supper klassificeres som kolde generelt, mens tørkost normalt er varmt, rimeligvis fordi den ved brug af ild er blevet afvandet.

Umiddelbart ser det ikke ud som en uoverkommelig opgave at servere tempereret mad i Juncal, men der er flere problemer: mennesket og dets legeme er også underkastet svingningerne omkring det tempererede balancepunkt. Ligesom en kylling ved sin kønsmodning går fra koldt til varmt, således er spæde og børn relativt kolde, og først med puberteten bliver man tempereret for endelig som gammel at være varm. Denne naturlige svingning skal imidlertid ikke modarbejdes, men respekteres, og derfor er det heldigt at modermælk er koldt. Der opstår imidlertid et problem når børnene går over til komælk, der er klassificeret som varm. Den må derfor altid tempereres med kolde urter som kamille og malve. Børn er erfaringsmæssigt mest udsat for varme sygdomme som feber og kolik, over for hvilke man bruger modvirkende medicinske planter. Generelt kan man sige at en syg tilstand modarbejdes med modsatrettede lægeurter, men en normal tilstand opretholdes med kost af tilsvarende temperatur. Sådan er det også med de gamle der netop bedømmes som varme fordi de især er udsat for kolde sygdomme som $\mathrm{fx}$ reumatisme. De skal derfor fortrinsvis spise mad der er varm.

Også i dagens løb er mennesket udsat for en naturlig svingning idet det føler sig koldere om morgenen og varmere om aftenen. Derfor skal man foretrække spiser der er kolde om morgenen, og det honoreres allerede ved at man får suppe eller vælling om morgenen, og i den udstrækning der spises tørre retter som kartofler med marsvin eller 
oksekød, som alle er varme, bydes de først fra hen på eftermiddagen. Som allerede omtalt gælder det modsatte princip i tilfælde af sygdom hvor en kur beroende på medicinske urter skal være domineret af den komplementære temperatur til sygdommen (Fock 1982), men det skal jeg ikke komme ind på her. Blot er det vigtigt at notere sig at mens de medicinske urter skal virke helbredende, så er maden altid af rent sygdomsforebyggende, opretholdende karakter.

Det bør lige omtales at ud over dette rationelle system for diætetisk madlavning findes der også enkelte eksempler på ren efterligningsmagi. Således er en yndet og styrkende ret for en ammende kvinde en suppe bl.a. kogt på kalvemule, angiveligt fordi der springer dråber frem på en sådan hvilket vil animere mælkeproduktionen.

Juncalenernes simple menu har vist sig mere kompliceret end som så. Kartoflens signalerende uskyld med hensyn til simpel behovstilfredsstillelse blander sig ikke blot med sansernes kortlægning af gastronomisk smag og behag, men også med det kølige intellekts systematik for en sundhedsmæssigt adækvat kost. Som omtalt udgør varmt-koldtdistinktionen et ad hoc-system hvor kategoriseringen er abstrakt, både hvad indhold og udtryk angår. At majs klassificeres i en kold kategori, er i sig selv ligegyldigt, det er blot en ad hoc-betegnelse. Men som vi har set, så er det samlede system i stand til at give mening, ligesom et sprog er. Man bringes nemlig i en position hvor man er i stand til at artikulere og begrunde den alsidige, sunde kost, ligesom man sættes i stand til at diagnosticere forskellige sygdomme ved at prøve sig frem først med den ene så med den anden slags kur.

En sådan teknik synes at have været gangbar overalt hvor civilisationer udvikledes: i klassisk græsk, indisk og kinesisk kultur såvel som i den mexicanske og andine. Den åbenbare begejstring for systemet, tror jeg, må søges i den særlige egenskab som varmtkoldt-distinktionen har: at denne dualisme ubesværet kan udtrykke såvel analoge som digitale procedurer. Det analoge, hvor man kan udmåle grader af henholdsvis varmt og koldt som på et liniestykke mellem de to ekstreme poler, er velegnet til fysiologisk og fysisk begrebsliggørelse, mens det digitale som et absolut enten-eller, ligesom i sproget, giver mulighed for den utvetydige kommunikation. Og det er jo netop transformationer mellem energi- og kommunikationssystemer der er på spil i forbindelse med maden.

\section{Udveksling af mad}

Indtil nu er juncalenernes brug af mad især skildret ud fra kroppens, sansernes og intellektets behov og behag, dvs. de sider af livet der dominerer den private sfære. Hvis man stiller spørgsmål til det indsamlede materiale med henblik på madens betydning i intimsfæren, så forekommer den anderledes end tilfældet ville være i Vesten. Der er ingen vidnesbyrd om at mad fx optræder som substitut eller symbol for sex; sex er i det hele taget påfaldende svagt profileret hvilket juncalenerne selv giver udtryk for. Mad i intimsfæren synes at indskrænke sig til ammesituationer.

Derimod antager maden nye og vigtige funktioner i den offentlige sfære, sådan som det blev omtalt i artiklens begyndelse. I alle livets forhold er mad og drikke det helt centrale middel til social differentiering, til accept eller foragt, til status for begge køn og til den højeste prestige. Inden for familiens kreds hersker den udvekslingsform vi kalder 
gaven, og det er husholdets ældre gifte kvinde der giver (convido) og helt bogstaveligt $\emptyset$ ser op til familiemedlemmerne, begyndende med manden.

Almindeligvis spises der i køkkenhuset (yanuna иси) hvor husmoderen er placeret ved et åbent ildsted med tre sten (tullpa). Nær familie kan uden videre forvente at blive bespist, men denne forventning kan ofte føre til at man netop undgår udeboende familie, for ikke at blive mistænkt for at pukke på sin ret. Således vil man også kun sjældent se et familiemedlem komme for at låne et par løg eller lidt sukker. Det sammenlignes med at tigge da man jo ikke behøver betale det tilbage. Altså må man hellere tage den lange tur til markedsbyen hvor man korrekt, men rigtignok både dyrt og besværligt, kan sikre sig det fornødne.

Således oprettes der på det sociale plan en diskontinuitet mellem udvekslingsformerne at give og at bytte. Sagen er at mad helt generelt synes at egne sig bedre til at give, og at kvinderne derved får en særstilling som de store givere. Derfor vil mange af de kvinder, der inviteres til en fest, medbringe et marsvin som værtindegave. Marsvin er gennem deres opdræt i køkkenerne naturligt knyttet til kvinderne, og de er kvindernes vigtigste middel til at vise generøsitet. Maden kan imidlertid på familieplan give anledning til betydelige spændinger. Normalt består et hushold af tre generationer hvor det ældre og yngre ægtepar deler køkken. Herved placeres svigerdatteren i en underordnet position og må - ofte i årevis - virke som tjenende ånd i køkkenarbejdet indtil hun og hendes mand får råd til at flytte ud som selvstændig familie.

Den anden form for udveksling, den balancerede reciprocitet, hører også privatsfæren til. Der er allerede givet eksempler på den med minga-arbejdet, men den udfolder sig især i forbindelse med afholdelsen af fester, som altid er forbundet med det religiøse, enten som helgenfester eller livscyklusfester. Når et ægtepar beslutter sig for at afholde en fest, indebærer det $\emptyset$ konomiske byrder, som familien slet ikke kan bære alene. Allerede et år forinden går man i gang med at skaffe mere eller mindre frivillige underleverandører til betaling af præst og sakristan, transport af harmonium, blomster og røgelse til kirken, bunker af store vokslys, fyrværkeri, et udendørs orkester, en ko til slagtning og mængder af brændevin, majsøl og mad. Omkostningerne løber let op i summer der ækvivalerer med to års landarbejderløn, en sum selv ikke den rigeste juncalbonde kan spare sammen. Festens sponsor sætter sig altså i en gæld, der må afvikles i årene der kommer, samtidig med at gamle skyldnere nu skal presses til at betale en genydelse. I gennemsnit afholdes der én religiøs fest om måneden og lige så mange dåbs-, hårskærings- og bryllupsfester hvor især de valgte gudfædre og -mødre spiller en rolle som donorer (compadrazgo).

Hvad familiefesterne angår, så er der specielt i forbindelse med bryllup anledning til at udtrykke sig symbolsk igennem maden. Man benytter det sigende udtryk ,at gifte sig med brød", som anses for særligt forpligtende. Det består i at brudgommens familie har bagt store mængder af ugærede boller formede henholdsvis som cabuya-planter (agavelignende achupalla) og duer (urpi), der ofte bygger rede i cabuyaen. Sådanne par af brød - ofte pyntet med blomster - foræres til de vigtigste gæster som et konkret symbol på etableringen af det unge hjem. Brødene er beregnet til at tage med hjem og indgår dermed i den kategori af mad, der kaldes wanlla. Ved bryllupsfesten foregår der også en rituel udveksling af mad idet gommen og hans gudfar sender den tallerken de får serveret over til bryllupshytten hvor bruden og hendes gudmoder modtager den og til gengæld returnerer deres egen. Når festen bliver mere løssluppen, opføres en kokkedans hvor et par af 
husets kvinder hvirvler rundt med skåle med mote og cui-spid, som de forsøger at løfte kvindernes skørter med.

Det som er væsentligt i forbindelse med udvekslingen af mad, er her at festerne har en klar treleddet struktur fordelt over tre dage, der kaldes vispera, fiesta og uyansa. Vispera er optakten hvor der i særdeleshed drikkes tæt, men også serveres mad til de indbudte gæster, der ud over slægtninge og compadres består af gode naboer og venner og eventuelt også nogle honoratiores og familier, man ønsker at forpligte til en senere fest.

Fiesta-dagen er så den dag hvor sponsorfamilien (pasador) kan sole sig i den prestige der vindes ved umådeholdent forbrug, hvor den dyrt betalte messe finder sted selvom man dog ikke altid er i stand til at deltage i på grund af for meget druk aftenen før.

Endelig er der uyansa, afslutningsgildet på den tredje dag, hvor alle der har hjulpet (ayudacuna), indbydes til den store takke-af-banket, som helst skal være det store overflødighedshorn af de bedste spiser, majskolber, mote, bønner, kartofler og rigeligt med chilisovs. Her bydes de fineste honoratiores (yuyacuna) der er bænkede ved selve bordet - fra dets hovedende og ned langs siderne - og de bedste $\varnothing$ konomiske st $\varnothing$ tter gerne et helt spidstegt marsvin, eller et halvt eller kvart til dem der ydede mindre. Måltidet kan omfatte 50-80 personer, også nogle snyltere der intet har bidraget (mucuridu), men dog betjenes om end sidst. Man bruger ordet uchuchina (chili-mad, egentlig ,at smøre“) for den fornemste servering, der fx kan blive en compadre til del for at vise respekt og taknemlighed.

Uyansa er en helt fundamental skik i Juncal; her er stadigvæk tale om den private reciprocitet mand og mand eller familie og familie imellem, men selvom festens værtspar forpligter sig til mangfoldige genydelser, så repræsenterer uyansa symbolsk gengælden i god mad og drikke. I et samfund uden magt og penge er det festsystemet og specielt uyansa der - gennem en persons placering i forhold til hovedbordenden samt opmærksom servering og nødning - udtrykker det hierarki af prestige der er magtens afløser i et afhængigt indiansk lokalsamfund.

Der er dog en situation hvor reciprociteten hører op, og det er ved døden. I løbet af sørgenatten hvor der drikkes tæt, har det været skik nogle steder at spille om afdødes fødevarer der står opstillet i kurve med klæde over. Spillederen bringer en hjemmelavet terning, tilskåret fra en kos løbebensknogle med varierende antal pointmærker på siderne (huayru), og den der kaster en femmer vinder. Gevinsten i dette hasardspil er afdødes madvarer, som vinder og spilleder deler.

Vi kan her konstatere at på det private plan indgår mad successivt i de klassiske tre former for reciprocitet: generaliseret i forbindelse med fødsler og amning, balanceret ved ægteskab og negativ reciprocitet i forbindelse med huayru-spillet ved dødsfald. For individet er den balancerede reciprocitet helt dominerende.

\section{Den offentlige banket}

Hvis festens givere er tilstrækkeligt flotte, kan han og hun sørge for at der af hensyn til eventuelle mestizer - som ofte inviteres fordi de er valgt som compadres, dvs. gudfædre og -mødre til familiens børn - også serveres ris og kylling, de hvides festmad svarende til indianernes kartofler og marsvin. Ikke fordi mestizerne ikke spiser marsvin, men fordi ris og kylling ligesom hvedebrød, på grund af den almindelige stigmatisering af indiansk 
mad og kultur i øvrigt, anses at være finere prestigemad. Det vil således demonstrere at festgiveren til fulde er i stand til at honorere herskende og konkurrerende kulturelle koder. Den enkelte sponsor indgår i et system af forpligtelser (cargos) til at afholde fester der - så længe det opretholdes - overskrider privat gensidighed og etablerer et omfattende redistributivt system. Man kan sammenligne det med et solidarisk skattesystem hvor de stærkeste skuldre bærer byrden, mens alle i samfundet har glæde af det. Denne institution, som for 40 år siden var meget mere formaliseret med årligt valgte civile og religiøse rollehavere, er stadigvæk virksom om end på mere uformel og frivillig basis.

I årets løb skaber det, som allerede omtalt, mulighed for afholdelse af en lang række fester hvor man vil være indbudt til nogle og eventuelt komme uinviteret til andre. Det skaber liv og afveksling i samfundet. Det daglige arbejde for det daglige udkomme afløses af socialt samvær med oplevelser som fyrværkeri og musik, med blomsteroptog og eventuelt messe. Den æstetiske dimension er påfaldende stærkt forbundet med festerne, og det gælder jo også maden når det bugnende bord af hvid mote og gule kartofler, kronet med skåle med rød chili og stegte marsvin, præsenteres.

Først skal maden vises, siden skal den spises. Ligesom ved den karnevalsbanket, der omtaltes i indledningen, så er der her tale om et show-off, en offentlig performance i mad hvor samfundet celebrerer sig selv. Når man deltager i sådan et festmåltid, som uyansa, er det en pligt at spise og drikke til overmål. Man skal blive overmæt og fuld, for man skal honorere generøsiteten, og - som juncalenerne siger - maven er jo den vigtigste del af kroppen, og både maden og majsøllet er mishqui (lækkert).

Den eneste måde man kan unddrage sig for meget brændevin på, er ved at bedyre at man uheldigvis netop har drukket mælk, som er klassificeret som varmt, og derfor støder sammen med den kolde brændevin og gør en syg. Andre undskyldninger duer ikke. Det kan minde os om - med en parafrase på Lévi-Strauss - at det også om mad gælder at den ikke blot er god at spise, men også god at tænke med.

Juncalenerne fastholder deres traditionelle madprofil, ikke mindst når det drejer som om festmaden, og fx uchuchina, den chili-spise man altid byder compadres og andre honoratiores, er symbolsk udtryk for denne tradition. Kendskab til ris og kylling som værende de hvides favoritmad, accentuerer kartofler og marsvin og majs og chili m.m. som etniske markører for indiansk livsstil og identitet. Sammen med dragten er maden simpelthen det stærkeste identitetstegn. Derfor er der også noget demonstrativt over den spektakulære festbanket, som i al sin relative simpelhed udtrykker så forbavsende meget om juncalenernes sociale og kulturelle liv.

At få serveret et helt spidstegt marsvin ved en fest er simpelthen det stærkeste udtryk for estimering og anerkendt prestige. Marsvin indtager en enestående plads i det juncalenske køkken, noget der også spores deri at det - i modsætning til ager- og husdyrbrugets andre produkter - ikke også fungerer som vare. Opvokset i et rent kvindeligt regi, nær ildstedet, bruges marsvin kun til familiens eget forbrug eller gives som værtindegave ved festerne. Marsvinekød anses i øvrigt for meget nærende og meget ,varmt“. Det gives derfor specielt til fødende kvinder, men da ikke stegt, men i form af suppekraft. Faktisk er marsvin højdepunktet i det juncalenske køkken både ud fra ernæringsmæssige, gastronomiske, sociale og følelsesmæssige synspunkter. 


\section{Afslutning}

Gennemgangen af maden i Juncal, diskursen om dens fremstilling, bydning og spisning, fortæller os at mad er kultur par excellence. Der er ikke tale om en fast størrelse eller ting, men om et repertoire, en samling implicitte opskrifter, der beror på fravalg og regler om kombinationer og relationer. Ligesom Marcel Mauss' totale sociale fænomener omfatter den alle livets aspekter, indgår i fysiske og sociale sammenhænge, i såvel den private som offentlige sfære på en lokalt karakteristisk måde, der til stadighed udfordres og langsomt ændres.

Man kan så spørge, på hvilken måde maden karakteriserer juncalensk kultur? Fremstillingen eller tilberedningen er kvindens ansvar, ledet af husholdets ældste, og som vi har set gemmer der sig betydelig viden om helse bag fremstillingen af en både nærende og afbalanceret kost. Fortæringen af maden omfatter naturligvis både mænd og kvinder, børn og gamle. Men selv om der principielt synes at herske en egalitær fordeling, så er der forhold der betinger at ældre mænd nok især har adgang til den mere prestigefyldte mad. Ved banketter sidder de nærmest opdækningen, og som gamle tildeles de flere „varme“ retter, herunder stegt marsvin og chili til den tørre mad. Fattigdom er dog et langt stærkere parameter idet det kan udelukke personer og hele familier fra den gode mad og henvise dem til noget nær nødrationer af machca. Endelig ser man individuelle præferencer især med hensyn til smagen idet nogle foretrækker søde eller salte retter frem for de stærkt chilikrydrede.

Ind imellem tilberedningen og spisningen, der er funderet på kulturelle normer, skyder sig serveringen, der afslører et mere afgørende socialt udvekslingsmønster i skellet mellem privat og offentligt regi. I privatlivet hersker den generaliserede reciprocitet hvor kvinden giver familien mad. Men i forbindelse med de offentlige fester, hvor maden er tilvejebragt ved sammenskud, er det, om end kvinderne stadigvæk har stået for tilberedningen, mændene og især de ærværdige mænd der - anbragt ved selve banketopdækningen - $\mathrm{i}$ praksis foretager fordelingen af maden til kvinder $\mathrm{og}$ børn i periferien.

Denne omvending accentuerer betydningen af at gå fra privat til offentligt regi i Juncal. I mange tilfælde kan man konstatere at det private liv er - og bør være - prunkløst, og at al æstetisering er henvist til det offentlige liv, fx udsmykning af kirken eller musik til processioner. Da vi under vort feltarbejde pyntede op i vores stue med grønt til julen, stirrede vor informant måbende på det og sagde: „Tilbeder I jer selv“? Til daglig og hjemme lever man yderst spartansk, og der er her ingen tegn på pynt så lidt som lækkerier i den daglige suppe. Alle ekstravagancer koncentreres om festerne, og for madens vedkommende om banketten hvor til gengæld intet er for meget eller for godt.

Maden afslører sig her som et tavst sprog, der også rummer en genre hvormed man mere spektakulært kan celebrere ikke sig selv, men samfundet som sådan. Man kan afsluttende sige om bankettens festmad at den i forhold til dagligdagskosten adskiller sig på en række punkter, bortset fra at de anvendte madvarer er identiske. Som tidligere nævnt karakteriseres dagligmaden som våd, vegetabilsk og stivelsesholdig, mens festmadens tilberedning er relativt meget mere tør og præget af animalsk protein. Banketten ændrer også udvekslingsformen fra reciprocitet til redistribution og gør anretningen til en performance hvor ærværdige mænd har overtaget kvindernes daglige distribution af føden og dermed gjort den til et offentligt anliggende. Dermed sætter den dagligkosten i skarpt relief. 


\section{Note}

1. Jeg har foretaget længerevarende feltarbejde i Juncal sammen med min kone, forskningsbibliotekar Eva Krener, i 1973-74 og 1977-78 og besøgt lokaliteten alene i 1962, 1984 og 1997. Artiklen bygger på egne feltnoter fra disse ophold. Jeg er Statens Humanistiske Forskningsråd og Københavns Universitet megen tak skyldig for den finansielle dækning af ekspeditionerne.

\section{Litteratur}

Archetti, E. P. 1997

Guinea-pigs: Food, Symbol and Conflict of Knowledge in Ecuador. Oxford: Berg Publishers.

Cordero, L.

1955

Diccionario Quichua-Español Español-Quichua. Quito: Casa de la Lectura Ecuatoriana.

1950

Enumeración botanica, Provincias del Azuay y Cañar (2 ed.). Madrid: Afrodisia Aquado.

Fock, N.

$1981 \quad$ Ecology and Mind in an Andean Irrigation Culture. Folk - Journal of the Danish Ethnographic Society 23:311-30.

1982 Mellem det varme og det kolde, diæt og filosofi i Andes. Jordens Folk 17(4):164-73.

Krener, E. \& N. Fock

1977/78 Good Luck and the Taita Carnaval. Folk - Journal of the Danish Ethnographic Society 19/20:151-70.

Sandoval, L. R.

1949 Vida económico-social del indio libre de la sierra ecuatoriana. Washington D.C.: The Catholic University of America Press.

Weismantel, M. J.

1988

Food, Gender and Poverty in the Ecuadorian Andes.

Philadelphia: University of Pennsylvania Press. 
